Article

\title{
Antecedents and Consequences of Frontline Employee's Trust-in-Supervisor and Trust-in-Coworker
}

\author{
Seonggoo Ji ${ }^{1}$ and Ihsan Ullah Jan ${ }^{2, *(D)}$ \\ 1 Department of Business Administration and Accounting, Hanbat National University, Daejeon 34158, Korea; \\ sgji@hanbat.ac.kr \\ 2 Department of Business Administration, Hanbat National University, Daejeon 34158, Korea \\ * Correspondence: ihsjan10@gmail.com
}

Received: 13 December 2019; Accepted: 16 January 2020; Published: 19 January 2020

\begin{abstract}
Based on social exchange theory, this study investigates the antecedents and consequences of a frontline employee's trust-in-supervisor and a frontline employee's trust-in-coworker in a single framework. A personally administered survey was conducted to collect data from 203 frontline employees of coffee shops in the Republic of Korea. Covariance-based structural equation modeling was applied using AMOS 21.0 to explore the proposed relationships. The results show that abusive supervision is negatively related to frontline employee's trust-in-supervisor, whereas supervisor support and communication quality have significant positive effects on frontline employee's trust-in-supervisor. Similarly, coworker ostracism has a significant negative effect on frontline employee's trust-in-coworker, whereas coworker harmony and communication quality have significant positive effect on frontline employee's trust-in-coworker. Finally, the results show that a frontline employee's trust-in-supervisor predicts a frontline employee's supervisor cooperation, and a frontline employee's trust-in-coworker leads to a frontline employee's coworker cooperation.
\end{abstract}

Keywords: frontline employees; trust-in-supervisor; trust-in-coworker; abusive supervision; supervisor support; communication quality; coworker ostracism; coworker harmony; supervisor cooperation; coworker cooperation

\section{Introduction}

Employees in general and frontline employees in particular are very important resources because of their significant roles in the overall operation of businesses. Similar to any other resource, the sustainability of human resources (i.e., frontline employees) is also important, and it is currently drawing immense attention in the literature. In the prior literature, a growing body of studies discusses this emerging phenomenon with different names, such as sustainable human resource management [1-3], green human resource management [4], socially responsible human resource management [5], and ethical human resource management [6]. Specifically, in the context of employees, one of the underlying ideas of aforementioned studies is fostering a long-term employment orientation and care for the employees [2,7], which are mostly determined by trust, loyalty, commitment, and equity in employment relationships [2]. Hence, it is important to further investigate these determinants in the context of organization's interpersonal relationships, such as relationship between employer and employees and/or employees to employees.

Specifically, in the literature, studies have explored interpersonal trust not only in the context of sustainable relationship but also to increase the desirable outcomes of employees such as job satisfaction, organizational commitment, organizational citizenship behavior, cooperation, and overall 
performance [7-11]. Despite the significance of interpersonal trust in organizations both for sustainable employment relationships and employee's positive attitudinal and behavioral outcomes, researchers in the past have given less attention to the determinants of the perceived interpersonal trust of frontline employees in supervisors and coworkers together. However, a handful studies in the prior literature have independently examined trust-in-supervisor and trust-in-coworker [12-18] Hence, there is a need to investigate interpersonal trust-specifically, frontline employees' trust-in-supervisor and frontline employees' trust-in-coworker in a single framework. This is because, the position of frontline employees is unique in that the attitude and behavior of frontline employees are generally influenced by their supervisors and coworkers. Similarly, in the prior literature, researchers have examined either the positive antecedents or negative antecedents of trust-in-supervisor and trust-in-coworker [13-17], yet the idea of integrating both the negative and positive antecedents of trust-in-supervisor and trust-in-coworker into a single framework is still underdeveloped and needs proper scholarly attention.

In order to address the aforementioned academic gaps, the current study attempts to extend the interpersonal trust of frontline employees into trust-in-supervisor and trust-in-coworker in a single framework. Moreover, the current study examines the relevant and unexplored positive and negative antecedents of trust-in-supervisor and trust-in-coworker in the context of frontline employees in a single framework. More precisely, the present study explores abusive supervision as a negative antecedent to trust-in-supervisor and supervisor support and communication quality as positive antecedent of trust-in-supervisor. In the same vein, the current study explores communication quality and coworker harmony as positive antecedents to trust-in-coworker and coworker ostracism as negative antecedent to trust-in-coworker. Similarly, along with antecedents of trust-in-supervisor and trust-in-coworker, the current study also shed lights on the consequences of frontline employees' trust-in-supervisor and frontline employees' trust-in-coworker. Specifically, the present study investigates the frontline employees' supervisor cooperation and frontline employee coworker cooperation as consequences of frontline employees' trust-in-supervisor and frontline employees' trust-in-coworker respectively.

The findings of this study may contribute to the theory and practice in several ways. First, the current study appears to be one of those developing studies that integrates the trust-in-supervisor and trust-in-coworker of frontline employees into a single framework. By doing so, the current study examines the unique position of frontline employees in the workplace, which are often influence by the supervisor as well as coworkers. Second, the present study may contribute to the literature of sustainable employment relationships by empirically investigating some of the positive and negative antecedents of frontline employees both of trust-in-supervisor and trust-in-coworker. Third, the findings of this study may contribute to the literature of employees' cooperative behaviors by examining the trust-in-supervisor and trust-in-coworker as predictors to frontline employees' supervisor cooperation and frontline employees' coworker cooperation respectively.

In addition, the results of the present study may provide insights to service managers and practitioners about the significance of trust-in-supervisor and trust-in-coworker for the sustainable employment relationships, such as the tendency of frontline employees to supervisor cooperation and coworker cooperation. Nonetheless, the findings of the study specifically the results of the proposed determinants to trust-in-supervisor and trust-in-coworker such as (a) abusive supervision, (b) supervisor support, (c) communication quality, (d) coworker ostracism, and (e) coworker harmony may help the service managers, human resource managers and other service intensive practitioners in the formulating strategies to enhance interpersonal trust (trust-in-supervisor and trust-in-coworker) in the organization.

This structure of this paper is organized as follow. First, we briefly discuss the social exchange theory that provides the theoretical framework for the study. Second, we review the prior literature about the key determinants of the frontline employee's trust-in-supervisor and trust-in-coworker, and based on that, we propose hypotheses of the study. Third, we explain about the data collection, data analysis, and results of the study in detail. Finally, we conclude the paper with the discussion, major theoretical and managerial contributions, limitations of the study, and the future research directions. 


\section{Literature Review}

\subsection{Social Exchange Theory}

Social exchange theory is one of the predominant theories to interpret social exchange relationships among parties in the setting of human interactions. Specifically, this theory has been frequently discussed in the literature to explain the social exchange between the employer and employees. In the context of social exchanges, the interactions of parties produce obligations [19] and interdependence on the action of the counterparts [20]. Cropanzano and Mitchell (2005) have explained that a social exchange occurs when employers treat nicely to their employees and the employees reciprocate to this with positive work attitudes and behaviors [21]. More precisely, the attitudes and behaviors of parties are governed by the norm of reciprocity [22]. In other words, if one of the parties perceives that the other party is fulfilling the social obligations, then the exchange process continues; however, if the party perceives it negatively, then the social exchange does not continue, and as a result, negative outcomes are likely occur. Drawing on social exchange theory, we investigate social interaction in the context of frontline employees, their supervisors and coworkers. Specifically, the current study discusses the positive and negative roles of supervisors and coworkers and their outcomes for frontline employes trust-in-supervisor and trust-in-coworker respectively.

\subsection{Abusive Supervision and Trust-in-Supervisor}

In the previous studies, trust has been discussed as important interpersonal variable which plays important role in the social exchange relationships. Mayer et al. (1995) defined trust as "the willingness of a party to be vulnerable to the actions of another party, based on the expectation that the other party will perform a particular action important to the trustor, irrespective of the ability to monitor or control that other party" (p. 712) [23]. To be very specific, frontline employees' trust-in-supervisor refers to willingness of frontline employees to rely upon the actions, promises, words or intentions of his/her immediate supervisor. Similarly, frontline employees' trust-in-coworker refers to willingness of frontline employees to rely upon the actions, promises, words, or intentions of his/her immediate coworker. In order to enhance the productivity of the working environment and the sustainability of the employment relationships, trust building plays a very pivotal role. Therefore, it is important to explore factors that increase or decrease the perceived trust-in-supervisor and trust-in-coworker of the subordinate. One of such unexplored factors which likely have effect on the trust-in-supervisor is abusive supervision.

Specifically, abusive supervision refers to "subordinates' perception of the extent to which their supervisors engage in sustained display of hostile, verbal and non-verbal behaviors excluding physical contact" (Tepper, 2000, p. 178) [24]. In the literature, researchers have listed some of the most predominant examples of abusive supervision, such as intimidation based on threat of firing, the non-disclosure of important information to subordinates, aggressive eye contact, the silent treatment, and humiliating or ridiculing someone in front of others [24-26]. A significant number of studies have discussed the outcomes of abusive leadership on the attitudes and behavioral outcomes of employees in the work place. For instance, researchers have shown that high abusive supervision significantly increase employee's moral disengagement [27], employees stress and turnover intentions, interaction avoidance [28], and organizational dehumanization [29]. Similarly, a meta-analytic review of the consequences of abusive supervision shows that abusive supervision has negative effect on the job satisfaction, affective commitment, and organization identification [30]. Social exchange theory argues that the attitude and behaviors of the parties are often govern by the norm of reciprocity [22], so the absence of positive social exchange therefore leads to negative results. Since trust-in-supervisor demonstrates the willingness of frontline employees to rely on the actions of the supervisor, abusive behaviors of the supervisor are therefore likely to have a negative effect on the perceived trust-in-supervisor of frontline employees. Therefore, consistent with findings of the above studies, we infer and propose that 
Hypotheses 1 (H1). Abusive supervision is negatively related to trust-in-supervisor.

\subsection{Supervisor Support and Trust-in-Supervisor}

In the workplace, supervisor support is defined "as individuals belief that supervisor offer them work-related assistance to aid in the performance of their job" (p. 181) [31]. In other words, supervisor support is a general perception of employees that their supervisors give recognition to their contributions and give significant attention to their well-being [32,33]. In particular, supervisors play significant roles in the trust development of employees [34-37]. Specifically, supervisor support is one of the major antecedents to trust-in-supervisor [38-41]. Similarly, supervisor support reduces the feelings of being miserable and increases the safety mind-set of an employee, which is a critical component of trust [23]. To be very specific, according to social exchange theory, the positive social exchange between supervisor and subordinate fosters the norm of reciprocity [22]. In other words, supervisory support may increase the perceived interpersonal trust of frontline employees to the supervisor.

Based on the findings of the above-mentioned studies, for the current study, we infer that supervisor support can be helpful to increase the trust-in-supervisor of frontline employees. This is because, frontline employees are generally doing challenging and multiple tasks, therefore, the assistances of supervisors in learning and successfully handling the responsibilities are crucial indicator of supervisory supports which likely increase their trust-in-supervisors. Hence, we propose

Hypothesis 2 (H2). Supervisor support is positively related to trust-in-supervisor.

\subsection{Communication Quality, Trust-in-Supervisor, Trust-in-Coworker}

Communication quality refers to the timely and accurately sharing of information through both formal and informal means [9,42-45]. In previous studies, communication has been discussed extensively, and studies have found that communication quality fosters trust in the organization $[45,46]$. More specifically, Yilmaz and Hunt (2001) have argued that the communication quality of coworker in the working places can increase a salesperson trust in coworkers [45]. Similarly, Ouedraogo and Ouakouak (2018) have studied the effects of communication in the change management process [47]. Their study revealed that communication leads to the affective commitment of the employees.

Conversely, some studies have also emphasized that failure in proper communication leads to deterioration of trust and more uncertainty [48]. Accordingly, in the context of service settings, supervisors, coworkers, and frontline employees perform together in order to produce high-quality services for customers. To be very specific, according to social exchange theory, the positive social exchange between supervisor and subordinate fosters the norm of reciprocity [22]. In other words, communication quality from the supervisor and coworkers may increase the perceived interpersonal trust of frontline employees. Therefore, we argue that communication quality in the workplace will increase the perception of trust-in-supervisor and trust-in-coworker of frontline employees because sharing information in a timely and accurate manner increases their confidences on their supervisors and coworkers. Hence, we propose

Hypothesis 3 (H3). Communication quality is positively related to trust-in-supervisor.

Hypothesis 4 (H4). Communication quality is positively related to trust-in-coworker.

\subsection{Coworker Ostracism and Trust-in-Coworker}

Workplace ostracism is defined as "the extent to which an individual perceives that he or she is ignored or excluded by others at work" (p. 1348) [49]. Ostracism is a social phenomenon that significantly impacts the way people treat others and are being treated by others [50,51]. More specifically, this is one of most prevailing social mistreatments in the work place. According to the findings of a survey of 1015 employees in various organizations, ostracism remained the highest ranked 
social mistreatment among employees $(70 \%)$ relative to bullying and social harassment [52]. To be very specific, based on the previous studies, coworker ostracism can be defined as "the extent to which the employees feel ignored or rejected by their coworkers." For instance, ignoring their opinions, giving less attention to them, or does not let them to give input to mutual assignments.

Prior studies show that workplace ostracism has negative effects on employees, such as deteriorating psychological well-being, reduced job satisfaction and commitment, job withdrawal, workplace deviance, and decreased organizational citizenship behaviors [49,53-56]. Social exchange theory argues that the attitude and behaviors of parties are often governed by the norm of reciprocity [22], so the absence of positive social exchange therefore leads to negative results. Consistent with these findings, for the present study, we argue that the coworker ostracism can have a detrimental effect on the perceived trust of frontline employees, which likely decreases their trust-in-coworkers. Hence, we propose

Hypothesis 5 (H5). Coworker ostracism is negatively related to trust-in-coworker.

\subsection{Coworker Harmony and Trust-in-Coworker}

Harmony is defined as the tendency to confirm and avoid conflict in a social interaction. Even though harmony is a relevant construct to the working place, yet it has not been drawn considerable attention in the previous studies of services marketing. In the literature a very handful studies have examined harmony in the context of marketing and organizational studies [57-60]. Specifically, as individual level construct, Chen et al. (2015) have investigated the effects of harmony on the creativity of employees [59]. Primarily, their study has explored the dualistic model of interpersonal harmony as harmony enhancement and disintegration avoidance and found that harmony enhancement has a positive relationship with the creativity of the employees. Similarly, few of the studies have shed light of the interpersonal harmony on attitudinal and behavioral outcomes of employees. For instance, Chin (2015) has explored harmony as one of the fundamental characteristics of Confucian ideology in the context of employees in China [61]. The findings of the study indicated that harmony has a significant positive effect on the employee's organizational citizenship behavior and job satisfaction. Based on social exchange theory, the positive social exchange among the parties fosters the norm of reciprocity [22]. Therefore, consistent with the findings of the above studies, we infer that a harmonious relationship among frontline employees can enhance their level of trust in each other. Hence, we hypothesize

Hypothesis 6 (H6). Coworker's harmony is positively related to trust-in-coworker.

\subsection{Trust-in-Supervisor, Trust-in-Coworker, Supervisor Cooperation, Coworker Cooperation}

In the prior literature, trust has been investigated, and various outcomes are highlighted. For instance, trust reduces perceived uncertainty, facilitates risk-taking behavior, and develops a cooperative and/or constructive orientation $[9,23,45,62]$. Similarly, some researchers have argued that trust is an immediate antecedent of cooperation $[9,45,63,64]$.

Cooperation refers to "the willful contributions of individuals, groups, and so on, to the successful completion of common tasks and/or to the achievement of mutual objectives" [45] (p. 335). Specifically, frontline employee's supervisor cooperation refers to the willful contributions of frontline employees to their supervisors in order to complete the common tasks. Similarly, frontline employees' cooperation can be defined as the willful contribution of frontline employees to their coworkers in order to complete the common tasks. Consistent with the findings of the aforementioned studies, for the current study, we propose that higher frontline employee trust-in-supervisor leads to higher frontline employee supervisor cooperation, and higher frontline employee trust-in-coworker predicts higher frontline employee coworker cooperation. This is because trust-in-supervisor and trust-in-coworker reflect that the actions and dealings of supervisor and coworkers will be beneficial, favorable, and not detrimental 
to the frontline employees, which likely increases their willful contribution in mutual activities. Thus, we propose that

Hypothesis 7 (H7). Trust-in-supervisor is positively related to supervisor cooperation.

Hypothesis 8 (H8). Trust-in-coworker is positively related to coworker cooperation.

Figure 1 shows the research model of the current study, which shows the antecedents and consequences of frontline employee trust-in-supervisor and trust-in-coworker. Specifically, abusive supervision, supervisor support, and communication quality are considered as antecedents to frontline employee trust-n-supervisor. Similarly, communication quality, coworker ostracism, and coworker harmony are examined as antecedents to frontline employee trust-in-coworker. In addition, supervisor cooperation and coworker cooperation are discussed as consequences of trust-in-supervisor and trust-in-coworker, respectively.

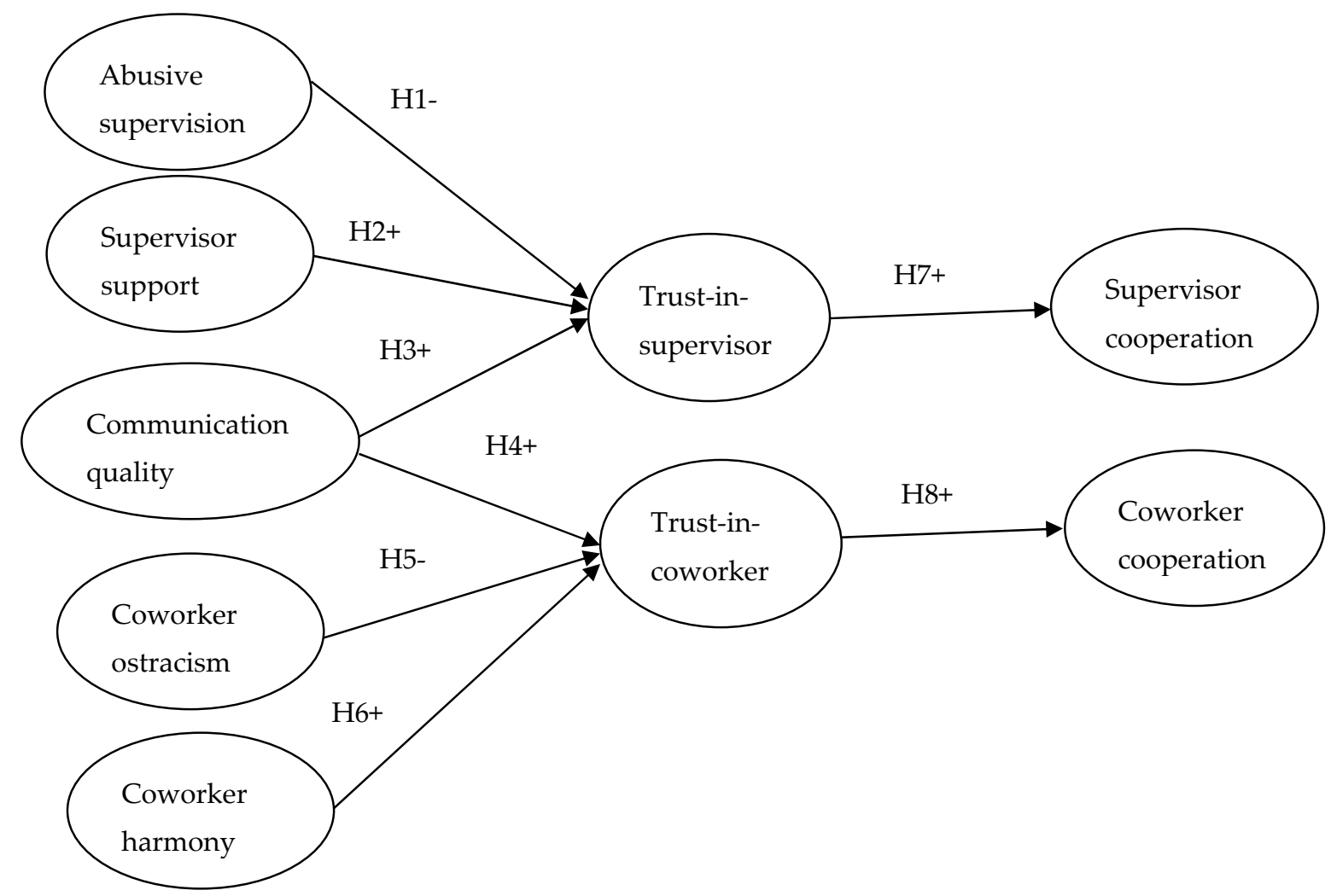

Figure 1. Research model.

\section{Method and Research Design}

\subsection{Sample and Data}

Data was collected through personally administered survey questionnaires. Primarily, the questionnaire was prepared in English and then translated into Korean in order to collect data with high precision and accuracy. The researchers have employed a back-translation approach in order to overcome the discrepancies of translation [65].

The study was conducted in the Republic of Korea, a country where interpersonal trust plays a significant role in every walk of life. Specifically, researchers in marketing, management, and behavioral studies have emphasized the significance of interpersonal trust in the operation of businesses $[66,67]$, and therefore, there is a need to explore the antecedents and consequences of frontline employees' interpersonal trust particularly trust-in-supervisor and trust-in-coworker. 
The unit of analysis of the study is frontline employees who work in coffee shops. Specifically, frontline employees are those employees of the coffee shops who directly interact with customers in delivering services and completing transactions. In the context of the Republic of Korea, a coffee shop is one of the most attractive businesses. For instance, a report in 2017 has shown that 26.5 billion cups of coffee were consumed in the previous year, which reveals that, on average, 512 cups were consumed by one person [68]. Such exponential growth of coffee shop businesses draws the scholarly attention of researchers to study various aspects of coffee shop services. In this regard, the study of antecedents and consequences of frontline employees' trust-in-supervisor and trust-in-coworker will be a substantial contribution to the theory and practice.

After preparing the final questionnaire in Korean, the researchers personally administered questionnaires to frontline employees in coffee shops located in Seoul and Changwon city from April 2018 to May 2018. Both these cities have the largest chain of coffee shops, and both cities are highly populated. Subsequently, a total of 230 questionnaires were collected and underwent initial screening. During the initial screening, the researchers first eliminated those questionnaires with missing data. Second, the researchers eliminated those questionnaires that reported either the absence of supervisors or coworkers. This is because the current study investigates antecedents and consequences of frontline employee trust-in-supervisor and frontline employee trust-in-coworker, so only those questionnaires should be retained for formal analysis that have reported the presence of supervisor and at least two coworkers in the coffee shop. Thus, the final sample size was reduced to $205(89.1 \%)$, which then underwent formal analysis.

Specifically, the final sample of 205 was comprised of 136 (67\%) females and 67 (33\%) males. The sample of the study reflects diversity based on frontline employees. The highest percentage were full-time workers $(70 ; 34.5 \%)$, followed by contract workers $(69 ; 34 \%)$. The largest numbers of respondents $(97 ; 47.8 \%)$ were professional college graduates, followed by $59(21.1 \%)$ college graduates. Table 1 discusses the demographic characteristics of the sample of the study in much detail.

Table 1. Demographic characteristics of respondents.

\begin{tabular}{cccc}
\hline & Demographics & Frequency & Percentage \\
\hline Gender & Male & 67 & 33.0 \\
& Female & 136 & 67.0 \\
Age & $10 \mathrm{~s}$ & 7 & 3.4 \\
& $20 \mathrm{~s}$ & 98 & 48.3 \\
& $30 \mathrm{~s}$ & 46 & 22.7 \\
& $40 \mathrm{~s}$ & 30 & 14.8 \\
& $\geq 22 \mathrm{~s}$ & 22 & 10.8 \\
Education & High school & 41 & 20.2 \\
& Professional college graduate & 97 & 47.8 \\
& College graduate & 59 & 21.1 \\
& University graduate & 6 & 3.0 \\
& Contract job & 69 & 34.0 \\
& Full time job & 70 & 34.5 \\
& Temporary job & 45 & 22.2 \\
& Managers & 19 & 9.4 \\
\hline
\end{tabular}

\subsection{Measurement}

The measurement items of the variables were taken and adapted from previous studies in the literature. The respondents used a five-point scale in which 1 stands for "strongly disagree" and 5 stands for "strongly agree" to respond to the questionnaire. Specifically, abusive supervision was measured by four items from the study by Mitchell and Ambrose (2007) [69]. Supervisor support was measured using three items taken from the existing scale [31]. Communication quality was measured by three items taken from Yilmaz and Hunt (2001) [45]. Similarly, coworker ostracism was measured using four items taken and adapted from the study of Wan, Chan, and Chen (2016) [70]. Coworker 
harmony was measured by the scale of Chin (2015) with three items [61]. Trust-in-supervisor and trust-in-coworker were assessed using five items taken from the study of Yilmaz and Hunt (2001) [45]. Supervisor cooperation and coworker cooperation were measured using four items taken from Yilmaz and Hunt (2001) [45]. Appendix A of the study shows all the variables and measurement items.

\subsection{Common Method Variance}

In order to collect data, a self-reported questionnaire was administrated to the respondents for both independent and dependent variables at the same time. Hence, the chances of common method bias increases, which may inflate the relationship among the variables. Therefore, we applied both procedural and statistical approaches to control for the common method bias [71]. To begin with, we assured the respondents that their responses would remain anonymous and only be used for the purpose of the research. Next, the respondents were also informed that there was no right or wrong answer and that their honest responses would be appreciated. Similarly, a statistical approach is also used to examine and control the common method bias. First, we used the Harman's single-factor method [72]. According to this method, we loaded the items of constructs in a single factor with an un-rotated factor solution. The results of the analysis showed that a single factor accounted for a $46 \%$ variance, which is less than $50 \%$ and confirms the absence of common method bias. We also repeated the Harman's single factor method in confirmatory factory analysis. We loaded all the items as indicators for a single factor. Malhotra et al. (2006) hold the view that "method biases are assumed to be substantial if the hypothesized model fits the data" (p. 1867) [73]. However, the results of confirmatory factor analysis of the single-factor revealed a poor fit to the data $\left(\chi^{2}=3808.98(\mathrm{df}=558\right.$, $p<0.00), \chi^{2} / \mathrm{df}=6.83, \mathrm{CFI}=0.53, \mathrm{TLI}=0.50, \mathrm{IFI}=0.53, \mathrm{RMR}=0.08, \mathrm{RMSEA}=0.17$ ), which further confirms the absence of common method bias.

\subsection{Data Analysis}

In order to test the proposed model, we used the two-step approach of analysis recommended by Anderson and Gerbing (1988) [74]. According to this recommendation, we checked the validity and reliability of the constructs from the measurement model and the hypotheses testing, and model fitness was measured by using "Covariance-Based Structural Equation Modeling" (CB-SEM) in AMOS V.21. SEM is a powerful tool to estimate different but interdependent, multiple regression equations in the model [75]. Also, SEM improves the statistical estimation of the relationships by taking into account of the measurement errors [75].

\section{Results}

\subsection{Reliability and Validity Analysis of Variables}

In order to check the validity of proposed model, the maximum likelihood method was applied by conducting confirmatory factor analysis (CFA) through AMOS 21. The results in Table 2 revealed that measurement model showed fit to the data $\chi^{2}=972.57(\mathrm{df}=521, p<0.00), \chi^{2} / \mathrm{df}=1.87, \mathrm{CFI}=0.93$, $\mathrm{TLI}=0.93, \mathrm{IFI}=0.94, \mathrm{RMR}=0.02, \mathrm{RMSEA}=0.06$. All the loadings were above 0.76 and significant on their respective factors. Further, the scale show high reliability, such as the Cronbach's alphas were great than the threshold cutoff of 0.70 . 
Table 2. Results of confirmatory factor analysis.

\begin{tabular}{|c|c|c|c|c|c|}
\hline Latent Variable & Items & Loadings $(\beta)$ & Cronbach's $\alpha$ & CR & AVE \\
\hline \multirow{4}{*}{ Abusive supervision } & ABS1 & 0.93 & \multirow{4}{*}{0.95} & \multirow{4}{*}{0.95} & \multirow{4}{*}{0.83} \\
\hline & ABS2 & 0.91 & & & \\
\hline & ABS3 & 0.90 & & & \\
\hline & ABS4 & 0.91 & & & \\
\hline \multirow{3}{*}{ Supervisor support } & SS1 & 0.83 & \multirow{3}{*}{0.89} & \multirow{3}{*}{0.89} & \multirow{3}{*}{0.72} \\
\hline & SS2 & 0.83 & & & \\
\hline & SS3 & 0.89 & & & \\
\hline \multirow{3}{*}{ Communication quality } & CQ1 & 0.88 & \multirow{3}{*}{0.90} & \multirow{3}{*}{0.91} & \multirow{3}{*}{0.76} \\
\hline & CQ2 & 0.91 & & & \\
\hline & CQ3 & 0.84 & & & \\
\hline \multirow{4}{*}{ Coworker ostracism } & $\mathrm{CO} 1$ & 0.87 & \multirow{4}{*}{0.94} & \multirow{4}{*}{0.94} & \multirow{4}{*}{0.80} \\
\hline & $\mathrm{CO} 2$ & 0.86 & & & \\
\hline & $\mathrm{CO} 3$ & 0.91 & & & \\
\hline & $\mathrm{CO} 4$ & 0.94 & & & \\
\hline \multirow{3}{*}{ Coworker harmony } & $\mathrm{CH} 1$ & 0.85 & \multirow{3}{*}{0.90} & \multirow{3}{*}{0.88} & \multirow{3}{*}{0.71} \\
\hline & $\mathrm{CH} 2$ & 0.88 & & & \\
\hline & CQ3 & 0.81 & & & \\
\hline \multirow{5}{*}{ Trust-in-supervisor } & TS1 & 0.85 & \multirow{5}{*}{0.93} & \multirow{5}{*}{0.90} & \multirow{5}{*}{0.70} \\
\hline & TS2 & 0.88 & & & \\
\hline & TS3 & 0.79 & & & \\
\hline & TS4 & 0.82 & & & \\
\hline & TS5 & 0.85 & & & \\
\hline \multirow{5}{*}{ Trust-in-coworker } & TC1 & 0.88 & \multirow{5}{*}{0.94} & \multirow{5}{*}{0.94} & \multirow{5}{*}{0.76} \\
\hline & TC2 & 0.80 & & & \\
\hline & TC3 & 0.93 & & & \\
\hline & TC4 & 0.85 & & & \\
\hline & TC5 & 0.89 & & & \\
\hline & SC1 & 0.83 & & & \\
\hline Supervisor cooperation & SC2 & 0.89 & & & \\
\hline supervisor cooperation & SC3 & 0.84 & 0.90 & 0.90 & 0.69 \\
\hline & SC4 & 0.76 & & & \\
\hline & CS1 & 0.87 & & & \\
\hline Courorker cooneration & CS2 & 0.90 & 0.90 & & \\
\hline Coworker cooperation & CS3 & 0.83 & & 0.91 & 0.71 \\
\hline & CS4 & 0.77 & & & \\
\hline
\end{tabular}

In addition, all the values of composite reliability (CR) and average variance extracted (AVE) were above the recommended cutoff values of 0.70 and 0.50 , respectively, which supports the high reliability and validity of measurements [76]. The square root of AVE is higher than the correlation between each construct, which further revealed the discriminant validity of the scale [70]. In order to check the multicollinearity, we examined the variance inflation factor (VIF) value. All the constructs of the study were considered as possible predictors and calculated the VIF. The results showed that the value of VIF are less than 3.60 which is less than the threshold value of 10, suggested a minimal collinearity [75]. Moreover, no outliers are reported in the dataset. All the inter-construct correlations and the square root of AVE of the constructs are reported in Table 3. 
Table 3. Correlation and with square root of average variance extracted (AVE) at the diagonal.

\begin{tabular}{lccccccccc}
\hline & $\mathbf{1}$ & $\mathbf{2}$ & $\mathbf{3}$ & $\mathbf{4}$ & $\mathbf{5}$ & $\mathbf{6}$ & $\mathbf{7}$ & $\mathbf{8}$ & $\mathbf{9}$ \\
\hline 1. Abusive supervision & $\mathbf{0 . 9 1}$ & & & & & & & & \\
2. Supervisor support & -0.47 & $\mathbf{0 . 8 5}$ & & & & & & & \\
3. Communication quality & -0.30 & 0.34 & $\mathbf{0 . 8 7}$ & & & & & & \\
4. Coworker ostracism & 0.72 & -0.35 & -0.47 & $\mathbf{0 . 9 0}$ & & & & & \\
5. Coworker harmony & -0.25 & 0.34 & 0.79 & -0.46 & $\mathbf{0 . 8 5}$ & & & & \\
6. Trust-in-supervisor & -0.67 & 0.59 & 0.46 & -0.54 & 0.52 & $\mathbf{0 . 8 4}$ & & & \\
7. Trust-in-coworker & -0.39 & 0.46 & 0.69 & -0.53 & 0.77 & 0.63 & $\mathbf{0 . 8 7}$ & & \\
8. Supervisor cooperation & -0.50 & 0.51 & 0.61 & -0.53 & 0.59 & 0.60 & 0.63 & $\mathbf{0 . 8 3}$ & \\
9. Coworker cooperation & -0.34 & 0.33 & 0.80 & -0.53 & 0.81 & 0.49 & 0.71 & 0.79 & $\mathbf{0 . 8 4}$ \\
\hline
\end{tabular}

All are significant at $p<0.01$.

\subsection{Hypotheses Testing}

In the next step, based on the recommendations of Anderson and Gerbing (1988), the structural model was tested [74]. The structural model analysis results show that the proposed model has a good fit, as the values are $\chi^{2}=1049.03(\mathrm{df}=449, p<0.01), \chi^{2} / \mathrm{df}=2.34, \mathrm{CFI}=0.91$, TLI $=0.90$, IFI $=0.91$, RMR $=0.07$, RMSEA $=0.08$, which fulfill the criteria of goodness of fitness and badness of fitness [77]. Table 3 provides a summary of the results of all proposed relationship of the current study. As the current study proposes in $\mathrm{H} 1$, a negative relationship between abusive supervision and trust-in-supervisor was supported by the results $(\beta=-0.45, p<0.01)$. Similarly, $\mathrm{H} 2$ of the study proposed that supervisor support leads to trust-in-supervisor, which was also supported by the results of the study $(\beta=0.30, p<0.01)$. H3 of the study argued that communication quality leads to trust-in-supervisor, which was also supported $(\beta=0.28, p<0.01)$. Similarly, the proposed relationship in the $\mathrm{H} 4$, that the communication quality has a positive relationship to the trust-in-coworker, was also supported ( $\beta=0.19, p<0.05$ ). Likewise, $\mathrm{H} 5$ of the study hypothesized that there is a negative relationship between coworker ostracism and trust-in-coworker, which was also supported from the findings of the study $(\beta=-0.20, p<0.01)$. H6 was supported by the study, which proposed that coworker harmony leads to trust-in-coworker $(\beta=0.56, p<0.01)$. Finally, H7 and H8 proposed that trust-in-supervisor and trust-in-coworker predict supervisor cooperation and coworker cooperation respectively, and both of the proposed relationship were supported by the results, as trust-in-supervisor leads to supervisor cooperation $(\beta=0.63, p<0.01)$ and trust-in-coworker leads to coworker cooperation $(\beta=0.74, p<0.01)$. Table 4 discusses the results of the study in detail.

Table 4. Results of SEM.

\begin{tabular}{cccccc}
\hline \multicolumn{2}{c}{ Relationship of Variables } & Hypotheses & $\boldsymbol{\beta}$ & Results \\
\hline Abusive supervision & $\rightarrow$ & Trust-in-supervisor & $\mathrm{H} 1(-)$ & $-0.45^{* *}$ & Supported \\
Supervisor support & $\rightarrow$ & Trust-in-supervisor & $\mathrm{H} 2(+)$ & $0.30^{* *}$ & Supported \\
Communication quality & $\rightarrow$ & Trust-in-supervisor & $\mathrm{H} 3(+)$ & $0.28^{* *}$ & Supported \\
Communication quality & $\rightarrow$ & Trust-in-coworker & $\mathrm{H} 4(+)$ & $0.19^{*}$ & Supported \\
Coworker ostracism & $\rightarrow$ & Trust-in-coworker & $\mathrm{H} 5(-)$ & $-0.20^{* *}$ & Supported \\
Coworker harmony & $\rightarrow$ & Trust-in-coworker & $\mathrm{H} 6(+)$ & $0.56^{* *}$ & Supported \\
Trust-in-supervisor & $\rightarrow$ & Supervisor cooperation & $\mathrm{H} 7(+)$ & $0.63^{* *}$ & Supported \\
Trust-in-coworker & $\rightarrow$ & Coworker cooperation & $\mathrm{H} 8(+)$ & $0.74^{* *}$ & Supported \\
\hline$\chi^{2}=1202.76, \mathrm{df}=539, \chi^{2} / \mathrm{df}=2.23, \mathrm{RMR}=0.06, \mathrm{RMSEA}=0.08, \mathrm{IFI}=0.91, \mathrm{TLI}=0.89, \mathrm{CFI}=0.90^{*} p<0.05^{* *} p<0.01$.
\end{tabular}

\section{Discussion and Conclusions}

Frontline employees, as an important resource of the firm, play a pivotal role in the operation of businesses. Therefore, researchers and practitioners give substantial importance to the determinants of their sustainable relationships. In this regard, drawing on social exchange theory, the current study was conducted to investigate the antecedents and consequences of frontline employees' trust-in-supervisor 
and trust-in-coworker. Unlike the previous studies, which examined the trust-in-supervisor and trust-in-coworker [12-18], the present study has integrated and examined the antecedents and consequences of trust-in-supervisor and trust-in-coworker in a single framework.

Drawing on social exchange theory, the findings of the study revealed that abusive supervision significantly decreased frontline employee's trust-in-supervisor. These findings are consistent with previous studies, which have shown that abusive supervision lead to employee's negative outcomes such as low job satisfaction [30], low affective commitment [30], low organizational identification [30], and employee stress and turnover intention [28]. Consistent with the previous studies, the current study also showed that supervisor support leads to frontline employees' trust-in-supervisor [38-41]. The findings of the present study also found that communication quality lead to frontline employees' trust-in-supervisor and frontline employees' trust-in-coworker. These findings have supported previous studies, which show that communication quality predicts interpersonal trust and organizational trust $[45,46]$. In the present study, we also investigated coworker ostracism as a negative antecedent to frontline employee trust-in-coworker. The results showed that coworker ostracism predicted the trust-in-coworker negatively, which also supported the idea that social ostracism in the workplace results in negative employee outcomes [49,53-56]. Similarly, the present study also investigated coworker harmony as a predictor for frontline employee trust-in-coworker, and the results supported the hypothesized relationship. These findings are new in the context of frontline employees; however, previous studies have discussed interpersonal harmony in the context of employee's creativity, organizational citizenship behavior, and job satisfaction [59,61]. Finally, the present study has shed light on the outcomes of frontline employee trust-in-supervisor and frontline employee trust-in-coworker. Specifically, the findings showed that frontline employees' trust-in-supervisor leads to supervisor cooperation, and frontline employees' trust-in-coworker leads to coworker cooperation. These findings are consistent with previous studies $[9,45,63,64]$; however, unlike the previous studies, the present study has investigated the relationships in the context of frontline employees of coffee shops.

\subsection{Theoretical Implications}

Theoretically, the current study has contributed to the literature of sustainable employment relationship in several ways. First, in the current study, we explored interpersonal trust in the context of frontline employees as an important determinant of sustainable employment relationships. Specifically, the current study has attempted to extend frontline employees' interpersonal trust into trust-in-supervisor and trust-in-coworker.

Second, the current study has investigated those positive and negative antecedents of frontline employees' trust-in-supervisor and frontline employees' trust-in-coworker that have gained less attention in the extant literature as important predictors of interpersonal trust. Specifically, on one hand, as positive antecedents of trust-in-supervisor, the current study has empirically tested the relationships of supervisor support and communication quality to trust-in-supervisor. On the other hand, abusive supervision was explored as a negative antecedent to trust-in-supervisor. Likewise, communication quality and coworker harmony were explored as positive antecedents to the trust-in-coworker and coworker ostracism was explored as a negative antecedent to trust-in-coworker.

Third, unlike previous studies, the current study has investigated the antecedents and consequences of trust-in-supervisor and trust-in-coworker of frontline employees in a single framework, which signifies the fact that the behaviors of frontline employees are influenced by supervisors and coworkers.

Finally, the current research has also contributed to the literature of employee's cooperative behaviors. Specifically, the present study explored frontline employee supervisor cooperation and frontline employee coworker cooperation as the consequences of frontline employee trust-in-supervisor and frontline employee trust-in-coworker respectively. 


\subsection{Managerial Implications}

As the sustainable employment relationship is important in every business, it is receiving substantial attention both in literature and practice. In line with this thought, the researchers in the current study have discussed interpersonal trust along with its determinants, which play a pivotal role in fostering employee's long-term orientation (i.e., frontline employees) and sustainable employment relationships in term of supervisor cooperation and coworker cooperation. The findings of this research provide new insights to service managers in understanding frontline employees' tendencies to trust-in-supervisor and trust-in-coworker. Specifically, this study has examined some of the overlooked antecedents that enhance and reduce trust-in-supervisor and trust-in-coworker in a single framework. Based on the results of the study, we have several managerial implications for service practitioners.

First, manager should educate supervisors about the negative outcomes of abusive supervision. The finding of this study reveal that abusive supervision in the workplace can deteriorate the perceived trust-in-supervisor, which eventually affects the tendency of cooperation of frontline employees to supervisors. Hence, in this regard, there is a need to formulate organizational policies that are based on organization-wide zero tolerance against abusive behaviors [78,79], which lead to sustainable employment relationships. Moreover, managers are also advised to improve the selection and recruitment process of supervisors in order to curtail the abusive supervision in the workplaces.

Second, managers should educate and train supervisors to be more supportive toward frontline employees. In order to enhance the supervisory support in the workplace, supervisor should be encouraged to extend their support in the form of assistance in performing tasks, provide helpful feedback, and giving recognition and appreciation to frontline employees. Consequently, such supportive supervision will increase frontline employees' level of trust in their supervisors, which will trigger their cooperative behaviors.

Third, the findings of the study revealed that communication quality of supervisor leads to trust-in-supervisor and trust-in-coworker. To be very specific, in this regard, managers should give more emphasis to the communication skills of applicants during the recruiting process. Moreover, service managers should offer extensive training and development workshops to supervisors and subordinates in order to improve communication quality in the workplace.

Fourth, coworker harmony is another antecedent which affects trust-in-coworker positively. Therefore, the service managers should play their role to create an environment where the frontline employees support each other to manage work-related difficulties and foster a friendly working environment.

Finally, the results show that coworker ostracism reduces the perception of trust-in-coworker of frontline employees. In this regard, service managers can adapt two approaches-specifically, a frontline employee-centric approach and a workplace-centric approach. To begin with, in a frontline-centric approach, the manager should educate frontline employees about the negative consequences (reduction of trust and cooperation) of coworker ostracism. In this regard, managers can initiate awareness programs such as workshops and seminars in the workplaces. Managers can also design exclusive training programs for those coworkers who are being frequently reported to be indulging in workplace ostracism in an intentional or unintentional manner. Moreover, managers can offer frontline employee assistance programs to cope with supervisor ostracism by promoting effective communication in the workplace [80]. In this regard, service organization can provide a confidential complaint-management which encourages frontline employees to report coworker ostracism incidents in the workplace. Finally, in a workplace-centric approach, the manager should formulate a strict code of conduct in the organization. In this regard, service organization can encourage and provide environment to the frontline employees to make compliance with the anti-bullying laws of the Republic of Korea, which were recently introduced [81]. 


\subsection{Limitations and Future Research}

Even though the current research has contributed significantly to the sustainable employment relationship literature and practices, like any other study, there are several limitations that should be considered in future studies. To begin with, the current research is based on self-reported cross-sectional data. Because of that, there is a high chance of common method bias. Therefore, future research should be in a longitudinal manner to further validate these findings. Next, for the present study, we collected data from the frontline employees of a single industry-coffee shops in the Republic of Korea-which limits the generalizability of the findings. Therefore, the collection of data across a range of service organizations in various service industries could enhance the generalizability of the findings. Finally, the current study has emphasized the interpersonal variables in the organizations and investigated the antecedents and consequences of frontline employees' trust-in-supervisor and frontline employees' trust-in-coworker. Therefore, there is a need for future research that further discusses organizational variables such as trust-in-organizations.

Author Contributions: Conceptualization and methodology I.U.J., S.J.; Supervision and validation, S.J.; formal analysis, I.U.J.; Original draft preparation, I.U.J.; Writing—review and editing, I.U.J. and S.J. All authors have read and agreed to the published version of the manuscript.

Funding: This research was supported by the research fund of Hanbat National University in 2018.

Conflicts of Interest: The authors declare no conflict of interest.

\section{Appendix A}

Abusive supervision

1. My supervisor says my thoughts or feelings are stupid.

2. My supervisor puts me down in front of others.

3. My supervisor makes negative comments about me to others.

4. My supervisor tells me I am incompetent.

Supervisor support

1. I find my supervisor very helpful in performing my customer service duties.

2. When performing my service duties, I rely heavily on my supervisor.

3. My supervisor provides me with important work-related information and advice that make performing my job easier.

Communication quality

In working relationship with my coworker and supervisor,

1. We keep each other informed of new developments.

2. We provide each other with timely information.

3. We frequently discuss accounts and opportunities.

Coworker ostracism

1. In general, I feel being ignored by my coworkers.

2. My coworkers often explicitly criticized my opinions/suggestions in the meeting.

3. My coworkers often disagreed with my suggestions at work.

4. In general, I feel being rejected by my coworkers.

Coworker harmony

1. I and my colleagues help each other to overcome difficulties. 
2. I and my colleagues maintain a friendly working atmosphere.

3. I and my colleagues exercise a fair competition.

Trust-in-supervisor

I consider my supervisor as people who(m)

1. Is/are perfectly honest.

2. Can be trusted completely.

3. Can be counted on to do what is right.

4. Can be counted on to get the job done right.

5. Has/have high integrity.

Trust-in-coworker

I consider my co-worker as people who(m)

1. Is/are perfectly honest.

2. Can be trusted completely.

3. Can be counted on to do what is right.

4. Can be counted on to get the job done right.

5. Has/have high integrity.

Supervisor cooperation

To what extent do you cooperate with your supervisor by;

1. I work with them to develop sales presentation techniques.

2. Taking care of their customers during their absence.

3. Providing feedback for improving their performance.

4. Handling their customer's complaints in their absence.

Coworker cooperation

To what extent do you cooperate with your coworker by;

1. I work with them to develop sales presentation techniques.

2. Taking care of their customers during their absence.

3. Providing feedback for improving their performance.

4. Handling their customer's complaints in their absence.

\section{References}

1. Ehnert, I. Sustainable Human Resource Management: A Conceptual and Exploratory Analysis from a Paradox Perspective; Springer: Heidelberg, Germany, 2009.

2. Stankevičiūtè, Ž.; Savanevičienè, A. Designing sustainable HRM: The core characteristics of emerging field. Sustainability 2018, 10, 4798. [CrossRef]

3. Kramar, R. Beyond strategic human resource management: Is sustainable human resource management the next approach. Int. J. Hum. Resour. Manag. 2014, 25, 1069-1089. [CrossRef]

4. Renwick, D.W.; Redman, T.; Maguire, S. Green human resource management: A review and research agenda. Int. J. Manag. Rev. 2013, 15, 1-14. [CrossRef]

5. Shen, J.; Jiuhua Zhu, C. Effects of socially responsible human resource management on employee organizational commitment. Int. J. Hum. Resour. Manag. 2011, 22, 3020-3035. [CrossRef]

6. Greenwood, M. Ethical analyses of HRM: A review and research agenda. J. Bus. Ethics 2013, 114, 355-366. [CrossRef]

7. App, S.; Merk, J.; Büttgen, M. Employer branding: Sustainable HRM as a competitive advantage in the market for high-quality employees. Manag. Rev. 2012, 23, 262-278. [CrossRef] 
8. Flaherty, K.E.; Pappas, J.M. The role of trust in salesperson-sales manager relationships. J. Pers. Sell. Sales Manag. 2000, 20, 271-278.

9. Morgan, R.M.; Hunt, S.D. The commitment-trust theory of relationship marketing. J. Mark. 1994, 58, $20-38$. [CrossRef]

10. Mulki, J.P.; Jaramillo, F.; Locander, W.B. Effects of ethical climate and supervisory trust on salesperson's job attitudes and intentions to quit. J. Pers. Sell. Sales Manag. 2006, 26, 19-26. [CrossRef]

11. Rich, G.A. The sales manager as a role model: Effects on trust, job satisfaction, and performance of salespeople. J. Acad. Mark. Sci. 1997, 25, 319-328. [CrossRef]

12. Ertürk, A. Increasing organizational citizenship behaviors of Turkish academicians: Mediating role of trust in supervisor on the relationship between organizational justice and citizenship behaviors. J. Manag. Psychol. 2007, 22, 257-270. [CrossRef]

13. Knoll, D.L.; Gill, H. Antecedents of trust in supervisors, subordinates, and peers. J. Manag. Psychol. 2011, 26, 313-330. [CrossRef]

14. Simha, A.; Stachowicz-Stanusch, A. The effects of ethical climates on trust in supervisor and trust in organization in a Polish context. Manag. Decis. 2015, 53, 24-39. [CrossRef]

15. Chughtai, A.; Byrne, M.; Flood, B. Linking ethical leadership to employee well-being: The role of trust in supervisor. J. Bus. Ethics 2015, 128, 653-663. [CrossRef]

16. Tan, H.H.; Lim, A.K. Trust in coworkers and trust in organizations. J. Psychol. 2009, 143, 45-66. [CrossRef]

17. Lau, D.C.; Liden, R.C. Antecedents of coworker trust: Leaders' blessings. J. Appl. Psychol. 2008, 93, 1130-1138. [CrossRef]

18. Atuahene-Gima, K.; Li, H. When does trust matter? Antecedents and contingent effects of supervisee trust on performance in selling new products in China and the United States. J. Mark. 2002, 66, 61-81. [CrossRef]

19. Emerson, R.M. Social exchange theory. Ann. Rev. Sociol. 1976, 2, 335-362. [CrossRef]

20. Blau, P.M. Social Exchange Theory; John Wiley: New York, NY, USA, 1964.

21. Cropanzano, R.; Mitchell, M.S. Social exchange theory: An interdisciplinary review. J. Manag. 2005, 31, 874-900. [CrossRef]

22. Gouldner, A.W. The norm of reciprocity: A preliminary statement. Am. Sociol. Rev. 1960, 25, 161-178. [CrossRef]

23. Mayer, R.C.; Davis, J.H.; Schoorman, F.D. An integrative model of organizational trust. Acad. Manag. Rev. 1995, 20, 709-734. [CrossRef]

24. Tepper, B.J. Consequences of abusive supervision. Acad. Manag. J. 2000, 43, 178-190.

25. Aryee, S.; Chen, Z.X.; Sun, L.Y.; Debrah, Y.A. Antecedents and outcomes of abusive supervision: Test of a trickle-down model. J. Appl. Psychol. 2007, 92, 191-201. [CrossRef] [PubMed]

26. Keashly, L. Emotional abuse in the workplace: Conceptual and empirical issues. J. Emot. Abus. 1998, 1, 85-117. [CrossRef]

27. Valle, M.; Kacmar, K.M.; Zivnuska, S.; Harting, T. Abusive supervision, leader-member exchange, and moral disengagement: A moderated-mediation model of organizational deviance. J. Soc. Psychol. 2019, 159, 299-312. [CrossRef]

28. Peltokorpi, V. Abusive supervision and emotional exhaustion: The moderating role of power distance orientation and the mediating role of interaction avoidance. Asia Pac. J. Hum. Resour. 2019, 57, 251-275. [CrossRef]

29. Caesens, G.; Nguyen, N.; Stinglhamber, F. Abusive supervision and organizational dehumanization. J. Bus. Psychol. 2019, 34, 709-728. [CrossRef]

30. Zhang, J.; Liu, J. Is abusive supervision an absolute devil? Literature review and research agenda. Asia Pac. J. Manag. 2018, 35, 719-744. [CrossRef]

31. Susskind, A.M.; Kacmar, K.M.; Borchgrevink, C.P. How organizational standards and coworker support improve restaurant service. Cornell Hotel Restaur. Adm. Q. 2007, 48, 370-379. [CrossRef]

32. Maertz, C.P., Jr.; Griffeth, R.W.; Campbell, N.S.; Allen, D.G. The effects of perceived organizational support and perceived supervisor support on employee turnover. J. Organ. Behav. 2007, 28, 1059-1075. [CrossRef]

33. Stinglhamber, F.; Vandenberghe, C. Organizations and supervisors as sources of support and targets of commitment: A longitudinal study. J. Organ. Behav. 2003, 24, 251-270. [CrossRef]

34. Dirks, K.T.; Ferrin, D.L. Trust in leadership: Meta-analytic findings and implications for research and practice. J. Appl. Psychol. 2002, 87, 611-628. [CrossRef] [PubMed] 
35. Holland, P.; Cooper, B.; Sheehan, C. Employee voice, supervisor support, and engagement: The mediating role of trust. Hum. Resour. Manag. 2017, 56, 915-929. [CrossRef]

36. Whitener, E.M.; Brodt, S.E.; Korsgaard, M.A.; Werner, J.M. Managers as initiators of trust: An exchange relationship framework for understanding managerial trustworthy behavior. Acad. Manag. Rev. 1998, 23, 513-530. [CrossRef]

37. Zhang, A.Y.; Tsui, A.S.; Song, L.J.; Li, C.; Jia, L. How do I trust thee? The employee-organization relationship, supervisory support, and middle manager trust in the organization. Hum. Resour. Manag. 2008, 47, 111-132. [CrossRef]

38. Byrne, Z.S.; Pitts, V.E.; Wilson, C.M.; Steiner, Z.J. Trusting the fair supervisor: The role of supervisory support in performance appraisals. Hum. Resour. Manag. J. 2012, 22, 129-147. [CrossRef]

39. De Coninck, J.B. The effect of organizational justice, perceived organizational support, and perceived supervisor support on marketing employees' level of trust. J. Bus. Res. 2010, 63, 1349-1355. [CrossRef]

40. Neves, P.; Caetano, A. Commitment to change: Contributions to trust in the supervisor and work outcomes. Group Organ. Manag. 2009, 34, 623-644. [CrossRef]

41. Stinglhamber, F.; Cremer, D.D.; Mercken, L. Perceived support as a mediator of the relationship between justice and trust: A multiple foci approach. Group Organ. Manag. 2006, 31, 442-468. [CrossRef]

42. Anderson, J.C.; Narus, J.A. A model of distributor firm and manufacturer firm working partnerships. J. Mark. 1990, 54, 42-58. [CrossRef]

43. Anderson, E.; Weitz, B. The use of pledges to build and sustain commitment in distribution channels. J. Mark. Res. 1992, 29, 18-34. [CrossRef]

44. Smith, J.B.; Barclay, D.W. The effects of organizational differences and trust on the effectiveness of selling partner relationships. J. Mark. 1997, 61, 3-21. [CrossRef]

45. Yilmaz, C.; Hunt, S.D. Salesperson cooperation: The influence of relational, task, organizational, and personal factors. J. Acad. Mark. Sci. 2001, 29, 335-357. [CrossRef]

46. Bordia, P.; Hobman, E.; Jones, E.; Gallois, C.; Callan, V.J. Uncertainty during organizational change: Types, consequences, and management strategies. J. Bus. Psychol. 2004, 18, 507-532. [CrossRef]

47. Ouedraogo, N.; Ouakouak, M.L. Impacts of personal trust, communication, and affective commitment on change success. J. Organ. Chang. Manag. 2018, 31, 676-696. [CrossRef]

48. Schweiger, D.M.; Denisi, A.S. Communication with employees following a merger: A longitudinal field experiment. Acad. Manag. J. 1991, 34, 110-135.

49. Ferris, D.L.; Brown, D.J.; Berry, J.W.; Lian, H. The development and validation of the workplace ostracism scale. J. Appl. Psychol. 2008, 93, 1348-1366. [CrossRef] [PubMed]

50. Williams, K.D. Ostracism: The Power of Silence; The Guilford Press: New York, NY, USA, 2002.

51. Williams, K.D. Ostracism. Annu. Rev. Psychol. 2007, 58, 425-452. [CrossRef]

52. O'Reilly, J.A.E.; Robinson, S.L. The negative impact of ostracism on thwarted belongingness and workplace contributions. In Academy of Management Proceedings; Academy of Management: New York, NY, USA, 2009.

53. Hitlan, R.T.; Cliffton, R.J.; DeSoto, M.C. Perceived exclusion in the workplace: The moderating effects of gender on work-related attitudes and psychological health. N. Am. J. Psychol. 2006, 8, 217-236.

54. O'Reilly, J.; Robinson, S.L.; Berdahl, J.L.; Banki, S. Is negative attention better than no attention? The comparative effects of ostracism and harassment at work. Organ. Sci. 2014, 26, 774-793. [CrossRef]

55. Hitlan, R.T.; Noel, J. The influence of workplace exclusion and personality on counterproductive work behaviours: An interactionist perspective. Eur. J. Work Organ. Psychol. 2009, 18, 477-502. [CrossRef]

56. Wu, L.; Wei, L.; Hui, C. Dispositional antecedents and consequences of workplace ostracism: An empirical examination. Front. Bus. Res. China 2011, 5, 23-44. [CrossRef]

57. Bakker, A.B.; Van Emmerik, H.; Van Riet, P. How job demands, resources, and burnout predict objective performance: A constructive replication. Anxiety Stress Coping 2008, 21, 309-324. [CrossRef] [PubMed]

58. Chen, C.C.; Unal, A.F.; Leung, K.; Xin, K.R. Group harmony in the workplace: Conception, measurement, and validation. Asia Pac. J. Manag. 2016, 33, 903-934. [CrossRef]

59. Chen, T.; Leung, K.; Li, F.; Ou, Z. Interpersonal harmony and creativity in China. J. Organ. Behav. 2015, 36, 648-672. [CrossRef]

60. Chin, T.; Liu, R.H. Understanding labor conflicts in Chinese manufacturing: A Yin-Yang harmony perspective. Int. J. Confl. Manag. 2015, 26, 288-315. [CrossRef] 
61. Moorman, C.; Deshpande, R.; Zaltman, G. Factors affecting trust in market research relationships. J. Mark. 1993, 57, 81-101. [CrossRef]

62. Chin, T. Harmony and organizational citizenship behavior in Chinese organizations. Int. J. Hum. Resour. Manag. 2015, 26, 1110-1129. [CrossRef]

63. Jones, G.R.; George, J.M. The experience and evolution of trust: Implications for cooperation and teamwork. Acad. Manag. Rev. 1998, 23, 531-546. [CrossRef]

64. Ring, P.S.; Van de Ven, A.H. Developmental processes of cooperative interorganizational relationships. Acad. Manag. Rev. 1994, 19, 90-118. [CrossRef]

65. Brislin, R.W. Back-translation for cross-cultural research. J. Cross-Cult. Psychol. 1970, 1, 185-216. [CrossRef]

66. Goo, J.; Huang, C.D. Facilitating relational governance through service level agreements in IT outsourcing: An application of the commitment-trust theory. Decis. Support Syst. 2008, 46, 216-232. [CrossRef]

67. Nedkovski, V.; Guerci, M.; De Battisti, F.; Siletti, E. Organizational ethical climates and employee's trust in colleagues, the supervisor, and the organization. J. Bus. Res. 2017, 71, 19-26. [CrossRef]

68. The Korea Herald. Available online: http://www.koreaherald.com/view.php?ud=20180218000032 (accessed on 6 January 2020).

69. Mitchell, M.S.; Ambrose, M.L. Abusive supervision and workplace deviance and the moderating effects of negative reciprocity beliefs. J. Appl. Psychol. 2007, 92, 1159-1168. [CrossRef] [PubMed]

70. Wan, E.W.; Chan, K.W.; Chen, R.P. Hurting or helping? The effect of service agents' workplace ostracism on customer service perceptions. J. Acad. Mark. Sci. 2016, 44, 746-769. [CrossRef]

71. Spector, P.E. Using self-report questions in OB research: A comment on the use of a controversial method. J. Organ. Behav. 1994, 15, 385-392. [CrossRef]

72. Podsakoff, P.M.; MacKenzie, S.B.; Lee, J.Y.; Podsakoff, N.P. Common method biases in behavioral research: A critical review of the literature and recommended remedies. J. Appl. Psychol. 2003, 88, 879-903. [CrossRef] [PubMed]

73. Malhotra, N.K.; Kim, S.S.; Patil, A. Common method variance in IS research: A comparison of alternative approaches and a reanalysis of past research. Manag. Sci. 2006, 52, 1865-1883. [CrossRef]

74. Anderson, J.C.; Gerbing, D.W. Structural equation modeling in practice: A review and recommended two-step approach. Psychol. Bull. 1988, 103, 411-423. [CrossRef]

75. Hair, J.F.; Black, W.C.; Babin, B.J.; Anderson, R.E.; Tatham, R.L. Multivariate Data Analysis, 7th ed.; Pearson: New York, NY, USA, 1998.

76. Fornell, C.; Larcker, D.F. Structural equation models with unobservable variables and measurement error: Algebra and statistics. J. Mark. Res. 1981, 18, 382-388. [CrossRef]

77. Bagozzi, R.P.; Yi, Y. On the evaluation of structural equation models. J. Acad. Mark. Sci. 1988, 16, 74-94. [CrossRef]

78. Restubog, S.L.D.; Scott, K.L.; Zagenczyk, T.J. When distress hits home: The role of contextual factors and psychological distress in predicting employees' responses to abusive supervision. J. Appl. Psychol. 2011, 96, 713-729. [CrossRef] [PubMed]

79. Gonzalez-Morales, M.G.; Kernan, M.C.; Becker, T.E.; Eisenberger, R. Defeating abusive supervision: Training supervisors to support subordinates. J. Occup. Health Psychol. 2018, 23, 15-162. [CrossRef] [PubMed]

80. Yang, J.; Treadway, D.C. A social influence interpretation of workplace ostracism and counter-productive work behavior. J. Bus. Ethics 2018, 148, 879-891. [CrossRef]

81. BBC NEWS. Available online: https://www.bbc.com/news/business-49000046 (accessed on 25 November 2019).

(C) 2020 by the authors. Licensee MDPI, Basel, Switzerland. This article is an open access article distributed under the terms and conditions of the Creative Commons Attribution (CC BY) license (http://creativecommons.org/licenses/by/4.0/). 